\title{
Analysis on the Death of Edna in The Awakening
}

\author{
XIONG Ya-qing, JIA Xiao-yun \\ University of Shanghai for Science and Technology, Shanghai, China
}

\begin{abstract}
As for the ending part of The Awakening written by Kate Chopin, the heroine Edna embraces death in the sea. Before throwing herself into the sea, Edna has experienced the fiery and confusing interior journey. Through close reading, this paper, starting with the moral and ethical restrictions of a patriarchal society, makes deep analysis on the causes for the failure of Edna's fighting for self from three aspects, and aims to reveal the meaning of her death to herself and the society at that time.
\end{abstract}

Keywords: The Awakening, Edna, death, causes, meaning

\section{Introduction}

The Awakening is the representative work of Kate Chopin, who is a famous American woman writer in the 19th century. It's also regarded as a classic work of feminist literature. "This novel is abundant and profound in its interpretation from multiple perspectives” (Deng \& Peng, 2010, p. 56). Due to this feature, literary critics have studied The Awakening from the critical perspectives, ranging from feminism and existentialism to the analysis of symbolism, naturalism, modernism, and other literary schools. Most researches focus on the cross-generational significance of the heroine's self-consciousness and sing high praises of the heroine with the warrior spirit of a moth into the fire. As for the ending of this novel, most of them attribute Edna's death to some single reasons such as the failure of pursuing love, or the mental and cognitive distortion of the heroine. Few scholars dig deeply into the reasons behind Edna's death from the details of the text and analyze the significance of her death. Therefore, Edna's death deserves further exploration. Before her death, she has experienced both physical and mental awakening. The reason why The Awakening can be regarded as a classic work of feminism is not only for the boldness and pioneering theme of the work, but also for Kate Chopin's exquisite writing technique and the successful use of symbolic images, which set off women's delicate psychological states and emotions. Starting from the details of the text, this paper aims to truly understand Edna's character image by analyzing Edna's death, makes out the profound meaning of the author's arrangement of this ending, and thus revealing the significance of Edna's death to herself and the society at that time.

\section{Analysis on the Causes of Edna's Death}

\section{The Moral and Ethical Restrictions of a Patriarchal Society}

Edna's death is closely related to the social environment in which she lives. In the patriarchal society, she

XIONG Ya-qing, Bachelor's Degree, College of Foreign Languages, University of Shanghai for Science and Technology, Shanghai, China.

JIA Xiao-yun, Master's Degree, Associate professor, College of Foreign Languages, University of Shanghai for Science and Technology, Shanghai, China. 
feels suffocated by the constraints of traditional ethics. The rules of ethics constantly remind her of her duty and responsibility as a wife and mother. She is always told what to do and what not to do, which becomes the biggest obstacle in her pursuit of love, freedom, and self. As a wife, she is supposed to be a mild, virtuous, and submissive woman, emotionally loyal to her husband. As a mother, she is supposed to be a selfless guardian and dedicator who is willing to spread her wings for her children. The women living at Grand Isle do their best to play the perfect wife, "angel in the kitchen", good mother, and other roles that meet the traditional moral standards of a patriarchal society.

In the beginning, Edna is such a virtuous housewife in a wealthy businessman's family. She obeys her husband and helps to manage house affairs. Her husband, Mr. Pontellier, is considered by other women to be the best husband in the world. Nevertheless, Mr. Pontellier remains the voice of a patriarchal society, and his kindness to his wife is based on her unconditional submission to his absolute authority and family responsibilities. "His love for his wife is not pure love, but love for his possessions" (Duan, 2010, p. 67). When Edna's child Raoul seems to have got a fever, Mr. Pontellier blames Edna for her neglecting her duties by being indifferent to her son. Feeling a nameless depression, Edna is in tears in the night. Not only her husband, but in the eyes of others, Edna is considered an unqualified mother. Madame Ratignolle, on the other hand, is a good wife and also a good mother, perfectly conforming to social norms. Even in her great postpartum pains, she does not forget to remind Edna of her responsibilities as a mother. "Think of the children; think of them" (Chopin, 2013, p. 277). But for Edna, being a good wife and mother in line with the standards of a patriarchal society means losing herself, which is exactly what she cannot accept. She would rather give all her money and sacrifice her life than lose herself and freedom.

After awakening, Edna begins to resent her husband's behavior of giving orders. She removes the wedding ring, and stamps on the ring with her feet; she even refuses to attend the commercial activities every Tuesday without authorization. Mr. Pontellier cannot understand Edna's abnormal change. He is shocked and irritated. He turns to Edna's father. This Colonel father even instructs his son-in-law to strictly discipline his daughter. “'Authority, coercion are what is needed.' ... The Colonel was perhaps unaware that he had coerced his own wife into her grave” (Chopin, 2013, p. 177). Neither her husband nor her father has ever really understood Edna as an individual. Mr. Pontellier, by contrast, is more concerned with his business and reputation. Tired of the boring marriage life, Edna begins to pursue freedom and true love, serving her emotional void and women's sexual needs. She steps into two extramarital affairs. One is the true love she pursues in her heart, the romantic young man Robert. The other is to meet her sexual desire, Alcee Arobin. However, there is no doubt that extramarital love is unacceptable in that society. Under the rules of the patriarchal society, both relationships end in failure. Edna's behavior in pursuit of true love and freedom is just like drinking poison to quench thirst.

\section{The Impacts From the Family of Origin}

Edna's nature to pursue love in her life may stem from the trauma of her family of origin. Her mother passed away early. On account of the lack of maternal love and the oppression of the traditional authority of her father, Edna has never been nourished by love. If an individual is unable to self-regulate the hurt in the heart, it may develop into a certain psychological disorder. The growing pains make her desperate for the care and love. She cannot live without the desire and nourishment of love. Therefore, even after leaving her suffocating husband, she continues to look outward for affection and love. "She leaned over and kissed him ...The action was full of love and tenderness” (Chopin, 2013, p. 265). “'I love you,' she whispered, ...It was you who awoke 
me last summer out of a life-long, stupid dream” (Chopin, 2013, p. 269). Edna wakes up from the insensible sleep. As for her, the power of love is unlimited, which makes her able to feel emotions and vitality flowing through her whole body. Unfortunately, the fantasy lover Robert finally leaves Edna to save both his and Edna's reputation. Disillusioned by the pursuit of true love, she is swallowed up by loneliness, and everything seems eclipsed; there is nothing in the world worth her nostalgia.

In addition, due to the impacts from the experiences of young age, Edna is incompetent to undertake the responsibility of being a mother. "It seemed to free her of a responsibility which she had blindly assumed and for which Fate had not fitted her” (Chopin, 2013, p. 47). When Edna is a little girl, the role of her mother is in a state of vacancy. After Edna grows up, as for the ethical identity of a mother, Edna is totally at a loss. She keeps mixed feelings for her children, and experiences the process of change from ambiguous positioning to extreme rejection of her mother's ethical identity, which makes her suffer from mental torture. She gets to believe that the children bring more misery than joy. In the end, Edna even experiences a qualitative change in the way she perceives her children. She becomes so hostile to her children, "The children appeared before her like antagonists who had overcome her; who had overpowered and sought to drag her into the soul's slavery for the rest of her days. But she knew a way to elude them" (Chopin, 2013, p. 284). The "way to elude them" here implies the death. Edna has to choose death to escape from her mother's identity.

\section{The Contradiction of Edna's Own Character}

As the main heroine of the story, Edna undergoes a dramatic change in her own character. On the one hand, Edna is a brave warrior. She seeks the meaning of being an individual in the universe. She has a natural spirit of adventure, daring to challenge the traditional society. Child as she is, Edna has a rebellious character. She does not want to pray, so she gets away and runs to the prairie freely. When Edna grows up, she is also rebellious about marriage. Neither her father nor her sister approves of her marriage to Mr. Pontellier, a Catholic, but she insists on her marriage to him. Edna is fearless. She tries to swim for the first time and wants to go to the place where no person has been before. She boldly pursues her own love and starts her painting career. Finally, she chooses to end her life in the boundless mysterious sea. "The act of suicide, at that time, was a very fierce and daring act, and also an act of rebellion by Edna against tradition” (Wang, 2013, p. 52). She is just like a canary waiting to be let out of the cage. Edna desperately desires to control her own destiny.

On the other hand, she is sensitive and fragile. The Doctor Mandelet once said, "Woman, my dear friend, is a very peculiar and delicate organism-a sensitive and highly organized woman, such as I know Mrs. Pontellier to be, is especially peculiar” (Chopin, 2013, p. 164). The fragility of mind makes Edna unable to be a woman strong enough. Accordingly, the character of great contradiction and complexity makes Edna find it hard to seek her position. "At a very early period she had apprehended instinctively the dual life - that outward existence which conforms, the inward life which questions" (Chopin, 2013, p. 32). She is brave, regardless of the eyes of the world, and resolutely leaves her dreary marriage life, so she disdains the boring and secular life. Not only does she believe that Madame Ratignolle's marriage life is extremely dull and hopeless, but she views the wedding ceremony as one of the saddest scenes in the world. What's more, even the bloody scene of the parturition makes her feel so painful and uncomfortable-causing. However, she is reluctant to be as independent and isolated as Mademoiselle Reisz or devote herself entirely into painting. As a result, the endless inner conflicts and struggles turn her spiritual world into a purgatory raided by fear, anxiety, and boredom. 


\section{Conclusion}

In the ending part of the novel The Awakening, the sparkling sea, the naked body, and the exhausted mind, Edna finally sinks into the sea. "A bird with a broken wing was beating the air above, reeling, fluttering, circling disabled down, down to the water” (Chopin, 2013, p. 284). The path of awakening becomes the path of death. "For Edna's death, its significance and value have been full of controversy in literary criticism” (Long, 2009, p. 94). Her death is the result of the pursuit of love, freedom, and self-worth, as well as the fight and challenge to the whole patriarchal society. Although her death is not strong enough to change the nature of female oppression in a patriarchal society, "Her awakening brings the first rays of sunlight of freedom" (Wang, 2013, p. 53). On the way to find herself, she lost herself; on the way to abandon herself, she saved herself. "This ending is the inevitable arrangement which Kate Chopin makes for Edna's fate after rational consideration of the heroine and her living environment” (Long, 2009, p. 94). She finally gives up her quest for love, freedom, and self-worth. Perhaps in the afterlife she can be her true self and be free forever.

\section{References}

Chopin, K. (2013). The awakening (bilingual). Trans. Jiao, L. J. Beijing: Foreign Language Teaching and Research Press.

Duan, Z. C. (2010). Edna-the loner in the world of love. The Science Education Article Collects, 23, 67-68.

Deng, Z., \& Peng, L. (2010). The psychological archetype analysis of the process of automaticity of Edna-rereading The awakening of Kate Chopin. Journal of Beijing International Studies University, 86(10), 56-61.

Long, Y. (2009). Research on the ending of The awakening of Kate Chopin. Literature Education, 1, 94-95.

Wang, J. (2013). An analysis of the dilemma and struggles of Edna in The awakening. Writer Magazine, 8, 52-53. 